\title{
Total quality management - is it another fad?
}

\author{
J.H. Tinker MD, N.F. Jensen MD
}

Today three primary forces drive health care policy in America, namely efforts to control costs, improve access, and to produce and assure delivery of high quality care. The payors are demanding cost control as are the employers. The politicians spout their usual pap and platitudes about improving access of under or uninsured groups to health care. All too often much of organized medicine's activity can be summed up in three or four words, namely "preservation of income" or, worse, "preservation of $m y$ income." In all this rancour, quality often -gets overlooked.

Much of the rest of American industry has now discovered (amazingly enough) that in reality, in any business, there are only three legitimate ways to compete, namely price, access, and quality. Much of American industry has now discovered what the Japanese learned almost 40 years ago from W. Edwards Deming and John Juran, that quality, if it is built into a product or a service from its earliest conception, through its production, through its service life, can actually reduce cost, raise profit, establish long-time patterns of customer good will, and turn into the single most important cornerstone of growth for a company or an industry (or even a country).

This lesson was painful for American industry. Anyone who ever has owned a 1979 Ford will have participated in what may well have been the low point of industrial quality in America. During those horrible years from American-made products, as American customers turned to Japanese and other foreign-made goods, surveyor after surveyor asked these American customers why they were doing so. Over and over, they shouted "because these products are better." If the lay public could see that, one must wonder why the American industrialists did not. The answer is profoundly important. American industrialists, up to that time, almost en masse, believed that quality was antithetical to growth and profitability. They believed, as sacred dogma, that quality costs more.

In the early 1950's, two individuals who were completely unknown in the U.S., namely W. Edwards Deming of Boston and John Juran of New York, were invited by Japanese industrialists to consult in that country. Deming and Juran quickly sold the Japanese on the idea that eventual production of quality products required that the quality be built in from the very beginning of the entire process, not simply inspected at the door the way American companies traditionally operated then (many still do, unfortunately including the health care industry). They convinced these Japanese industrialists that by building quality into the product at every step in its manufacture, they could eliminate waste and rejected products, driving costs down dramatically and down far in excess of any added costs there might be in the production of quality. There were numerous side benefits, most importantly along the lines of company morale. When each worker was given the responsibility to produce quality rather than beaten over the head with some kind of financial (or physical) club if she/he produced a defective item, it was remarkable how worker morale improved in Japan. Meanwhile, in America, worker sabotage of various products (including instances of small steel boxes welded into the fender wells of automobiles with loose steel nuts inside to produce continuous rattles, and many other such anecdotes, symptoms of very sick manufacturing and service sectors.

Deming was finally accepted in America. His " 14 points" are required knowledge for every student MBA. At age 91, he is still going strong and has played a major role in what many hope will be a revitalization of American manufacturing and service sectors.

To understand the key point made by Deming, Juran, and others, one must understand a very basic difference in philosophy between these individuals who understood human nature quite well, and the American industrialists and managers who did not. Deming believed that by far the vast majority of workers truly desire to produce quality products. If that is true, and it clearly is, then if a quality product is not being produced, the flaw is not with the workers but rather with the system or the process. It follows that these same workers ought to be able to assist management in finding ways of improving the process. Further, this improvement effort ought to go on continuously, hence the term "continuous improvement" or "continuous quality improvement (CQI)." In America, a machinist whose job it is to produce a oneinch diameter shaft will very likely be given a drawing

From the Department of Anesthesia, University of Iowa Hospitals and Clinics, Iowa City, Iowa 52242. 
which says, 1.000 inches \pm 0.002 inches or some other tolerance. Further, that American machinist is given a "quota" of these products to produce in an eight-hour shift. In Japan, quite often, that same machinist would be simply given a drawing which states that the shaft is to be as close to 1.000 inches as can be done, and "please produce as many shafts as you can each day that are of high quality." Every day, to be sure, the average diameters of these shafts are recorded and carefully monitored by management. If something is out of whack, it is not automatically assumed that the worker is loafing, sluffing, or sabotaging, but rather that perhaps there is something wrong with the material, the process or the machine, etc. This kind of management attitude toward workers has had the most to do with the real revolution in quality that occurred in Japan and other countries. I continually find it amazing that it took nearly 40 years to bring it to America.

In truth, these concepts are still not practical in health care in any major way. There are many problems today concerning quality in the field of health care. Outcomes of care are largely unknown, there is a general impression that there are massive unmet needs, although at the same time there are perceptions of equally massive unnecessary expenditures for inefficacious or inappropriate treatments. It is our general impression that there are outrageous abuses of the health care system based on a perceived need by many physicians to practice "defensive" medicine. There are numerous examples of incredible variances in outcomes between hospitals or geographic regions. We know of massive duplication of services as, for example, lithotriptors have been installed in nearly every hospital of any size: multiple CAT scanners, numerous MRIs, and now PET scanners are seemingly everywhere. There is no doubt that patients today generally feel that they or their insurers (and they are getting much more sophisticated about the latter) are paying too much, getting too little or too impersonalized care; there is no doubt that in growing numbers they are dissatisfied with the overall quality and availability not to mention price of their care. Today the greatest consumer focus is on quality of medicine and not on its triumphs.

There are numerous instances of this concern with quality. Per capita health care expenditures for comparable patient populations were approximately twice as great in Boston as in New Haven. Studies have shown twoto three-fold differences common in rates of test ordering, surgery, drug use and hospitalization. Dr. Jack Wennberg, of Dartmouth, is a pioneer in this growing and disturbing field. He found that in one Maine county, $70 \%$ of women had undergone hysterectomies by the age of 70 whereas in a nearby county, that figure was only $20 \%$. That is really scary. In another study, $65 \%$ of carotid endarterectomies reviewed were considered questionably indicated as were $56 \%$ of Medicare-reimbursed pacemaker implantations. Before prospective payment began, Medicare admission rates differed by regions as much as $22 \%$ and length of stay by as much as $45 \%$.

What usually happens when physicians and/or hospitals and/or their professional societies are presented with such disturbing "Ralph Naderesque" data? Often the provider finds a complex or jargonistic way to say "my patients are sicker than yours. "Severity of illness indexing is now quite sophisticated. Massive data bases exist. Severity of illness indexing will likely produce startling results in the next few years. I doubt that the academic medical centres will necessarily always have the sickest patients! Most physicians do indeed have sick patients, as do most hospitals.

Currently, we spend $12 \%$ of our nation's gross national product, i.e., $12 \%$ of the total value of all goods and services delivered in the United States, on health care. Numerous expert projections consider that, at current rates of growth, this number will grow to $15 \%$ by the year 2000. No other major industrialized nation has health care spending of more than $10 \%$ of the GNP, and many considerably less than that. If the American health care system were considered to be a "nation" unto itself, that "nation" would currently have the 6th largest gross national product of all the real nations on this planet.

Not only do we not understand quality management, i.e., the Japanese philosophy of continuous quality improvement, we don't want to. In many ways, medicine, including anaesthesia, can best be likened to the "guilds" of the past. When the "Mom and Pop" corner grocery stores were threatened by larger chain establishments, they banded together to form a guild, some cities called it the IGA, namely the Independent Grocers Association. The idea was to get that word "independent" into the title. Along came Kroger, Safeway, Hy-Vee, etc., and you know the result. Why? The definition I like best for capitalism is that capitalism is simply the investment and use of capital. Corporate capitalistic America tackles perceived markets by investment and use of capital. What did Safeway, Kroger, Winn-Dixie, etc., do to beat the Mom \& Pop grocery stores? They competed with price, quality and access. They built huge stores, kept them open longer, tried hard to undercut local prices, kept quality constant and, often, kept quality high.

Most physicians, frankly, are blissfully unaware of the very real likelihood that the investment of capital, in much the same way as the grocery store analogy above, will soon be applied to delivery of medical care in the United States. Why not? When you go to Safeway, you get quality products, large selection, excellent store hours, plenty of parking, etc. To be sure, you do not necessarily 
have access to your own "produce person" or your own "butcher" whose name you know and can engage in friendly conversation every week. But you know that the quality of the products you are purchasing are backed up by a large organization that by and large does things with competence and skill. American customers, by the millions, have opted for this model of the delivery of food products, all the while telling politicians and surveyors that they miss the "good old days" i.e., the Mom and Pop store. Why won't these consumers opt for some kind of corporate model of health care delivery? Consumers very likely will move in the direction mentioned above if the delivery of that care can be better quality controlled and if the quality of that care can be continuously improved. The sacred "fee for service" system we think we have today is "nonsense." In the majority of patients, we submit a fee, the third party payors decide what they will pay us, and within limits, we accept that payment.

Do we really understand that the cornerstone of all the above is quality? Of the over 6,000 hospitals in the United States, how many have "troubled" anaesthesia departments? Of those that are "troubled," is quality continuously improved anaesthesia care really being delivered in those institutions? To be sure, in each hospital, the "troubles" are individual and local in nature, and often are characterized as "turf battles" or "competing groups picking at each other" or one kind of anaesthesia care provider trying to drive out another kind, e.g., anaesthetist versus nurse anaesthetist or vice versa. Under all these smoke screens is the issue of quality. Do we know how to measure it? Do we know how to define it? A leading thinker in this area is Donabedian, who defined quality of care in medicine as "that kind of care which is expected to maximize an inclusive measure of patient welfare, after one has taken account of the balance of expected gains and losses that attend the process of care in all its parts." This is an academically obtuse way of saying that quality is something most of us think we understand, but in fact each of us sees it differently. We really don't know much about measuring it in objective reproducible agreed-upon ways.

There is much confusion between the "quality" and the term "efficacy." A good way to understand "quality" is to answer the question "was the right thing done, and was it done right?" Such a "quality" determination requires previous knowledge of what is efficacious. Establishment of measurements and standards of quality require a foundation of real knowledge about efficacy. In many areas of medicine, especially surgery, the foundation of what is efficacious treatment is shaky at best. For example, with today's modern antibiotics, do we really need to do an appendectomy for appendicitis? Every time? What do we know about that issue? We know that appendicitis treated with appendectomy has a relatively low mortality and surgical/anaesthesia risk. We have no clue as to whether it is more or less efficacious than antibiotic therapy using modern drugs.

Wennberg argues that in order to get beyond this problem of lack of a firm foundation of efficacy, we must accept broad sets of indications for treatments if we are going to move on and try to establish reasonable indicators for quality. At the same time, nonetheless, Wennberg and many others believe that "it is of extraordinary importance to evaluate reasonably held, but inadequately tested, theories of treatment of common illness ... the task is manageable ... ". Wennberg contends that $60 \%$ of major surgical admissions to U.S. hospitals are for only 23 different operations. He further contends that about 40 acute and chronic illnesses make up over $70 \%$ of medical admissions. It is on these facts that he bases his contentions that legitimate studies of efficacy can and should be undertaken. Others, including myself, are nowhere near that optimistic, because, for one reason, Wennberg seems to ignore the economic power that the industry represented by each of these major medical and surgical treatments.

For example, when the Sandoz Pharmaceutical Company can sponsor a poll of 100 transplant physicians about whether or not the United States should have mandatory organ donation laws which require specific disapproval of organ donation, otherwise organs will be donated upon death (AMA News, November 4, 1991), we begin to understand how much economic power there is behind some of these treatments and how little interest there will be within the ranks of those who have that economic power in determining the efficacy of those treatments.

Despite the idealistic efficacy-first-then-quality approach taken by Wennberg and his colleagues (who live in Hanover, a town of 6,000 people, in New Hampshire) what is happening in the rest of the world in these arenas? Quite simply, the health care financing administration (HCFA) continually ratchets payment down for procedures it considers overused or under-efficacious or both. To understand this process, only one needs to understand what HCFA has done to coronary angioplasty over the last several years. Although I applauded HCFA's attempts to chop payments for this extremely questionable procedure, I do understand how arbitrary HCFA's attempts to do this were. In this arena, HCFA usually makes arbitrary, sometimes capricious, always budgetdriven decisions to ratchet down payment to physicians and see what happens. Some people believe that this is the only way that is ever going to be practical. Others believe that new procedures and/or new medical treat- 
ments, just like new drugs, should be required to show proof of efficacy before they are licensed to be performed and/or paid for by anyone. Would you agree to be in the "sham operated" group in a putative study of the efficacy of appendectomy? If you were in the "sham" group, you would receive an incision but no appendectomy and instead would receive high-dose antibiotics? Would you agree to this? Probably not. What I'm trying to say is that I don't believe that the proponents of socalled valid efficacy studies are likely to hold sway with respect to many of the financially established older procedures and/or medical therapies. The history of these therapies mostly shows that we abandon them when safer or more financially remunerative treatments come along rather than for reasons of efficacy.

What about quality assurance? This near-nonsense term implies that we already have quality, that we know how to measure it with confidence, and that all we're going to do is assure its continuation. What nonsense. Let us return to our Japanese 1.000 inch diameter shaft manufacturing process. If the products are determined to be of high quality, this particular process may not be targeted for any CQI activities in the near term, but management will be watching carefully. They are not watching the machinist per se, they are watching the quality of the output. If the quality seems to slip over time, they will not automatically blame the machinist. They will make a primary assumption that the machinist wants to turn out the best quality every time and that something is wrong with the system. I don't think I have to tell you what an American shop foreman will do and say. The American machinist will be given a quota and a tolerance. If either is not met, the machinist will be blamed. It is still a policeman's mentality often in America today.

Deming said "even if everyone in a company works to the very best of his/her capacity, with the very best intention, all the time, the company still will very likely fail because these well-intentioned hard working people must work together." Deming demanded that we design quality into the process from the beginning. Deming said "organize across departmental lines to solve problems." Hospitals (not just teaching hospitals) probably have more "microturf" than most modern institutions.

All across America, especially in industry but increasingly in hospitals, "total quality management" initiatives are forming. A few examples can underscore this point: getting patients to the operating suite on time in the morning is often a problem. A CQI group could be organized which would first develop a "flow chart" to understand every step involved in the process. Just doing this for this "simple" problem will convince everyone of the complexity of this process. The CQI group should be made up of the people who actually do the work with a CQI "facilitation" manager to lead the discussion. Once everyone understands what everyone else does and their problems, it is amazing how much improvement can be made. This is the essence of the philosophy of continuous improvement. This is almost exactly opposite to "quality assurance" with its useless finger pointing (see below). Operating room scheduling, operating room turnaround, excessive inventory of various surgical instruments or microscopes or lasers or fibrescopes, etc., all these problems can be tackled by CQI team approaches.

Deming said "develop long-term relationships with suppliers so that the suppliers can feel confident that they will have steady business into the future and therefore can develop ways of improving the products they supply." What do we do in hospitals instead? We buy drugs and equipment from different suppliers on an almost weekly "low bid" basis. As John Glen was about to be rocketed into space for the first U.S. earth orbit, he is alleged to have said, "Here I sit, on top of three million parts, all bought from the lowest bidder." The U.S. "low bid" idea is clearly antithetical to quality much of the time.

Deming said "break down barriers." What do we do in our anaesthesia departments? We have built numerous subunits of pseudo elitism. If I want to limit competition, one way is to make a "Board" and generate a "certification." This is all glossy antithetical to quality. In many larger departments, we have separate call units for cardiac, neuro, paediatrics, obstetrics, even pain management, etc. God forbid that some "ROA" (regular old anaesthetist) could actually be entrusted to do a postoperative bleeding CABG patient! Deming said "develop pride in workmanship." As we continue to build these elitist barriers, with subspecialty journals, subspecialty societies which look upon regular old anaesthetists with disdain, how can these "ROAs" develop much pride in what they do? What happens to the subsubsub-specialist who is suddenly required to do ROA?

Deming said "when you inspect products coming out of your plant, you will end up with basically three piles, acceptable items, rejected items that need to be scrapped (great cost), and rejected items that must be reworked (at great cost)." The same can be said for the output of our hospitals and medical schools. Deming said "build quality in all the way, not just inspect for it at the end and expect it to be there." What do we do in the medical business? We have virtually no interest about building quality into our medical or resident education processes. We seem resigned to waiting until some state board of medical examiners or the national boards or the American Board of Anesthesiology conducts some kind of examination at the end of a training period! In our hospitals, do we really try to build quality into the processes 
of residency training and patient care all along the way? For that matter, do we really try to build quality into the processes by which we do laboratory and/or clinical research? Our current methods of "quality assurance" are counterproductive and antithetical to quality. By "physician specific QA" we force ourselves to take the position that when there is a bad outcome, somebody must be blamed. Our PRO groups in each state are doing this, as all of you know, with a vengeance today. The "heads must roll" mentality produces defensive behaviour, not quality medicine. Does it help? You know that answer to that as did Deming $40 \mathrm{yr}$ ago. So did Juran $40 \mathrm{yr}$ ago. I am not saying we don't need to weed out the few true incompetents for whom negligence, corner cutting, lying and cheating are the usual ways of doing business. Deming was clearly correct, however, when he said that the vast majority of workers want to produce good jobs or provide good services. They do. We need to organize to listen to the workers and adopt a continuous improvement philosophy. Pollyannaish you say? Go look at a Japanese car or camera.

What about the education we received in medicine? It is fair to say that it was long, rigid, and sometimes, tyrannical, often dogmatic. It was far from what Deming advocated in terms of recognizing and unleashing individuality, ingenuity, and potential. With a system this harsh, is it possible that the caring, humanistic, and emphatic aspects of medicine which drew us into the field in the first place have become at least partly lost? Are we so afraid of our patients as potential legal adversaries that we have become rigidized into uncaring, unfeeling people who always apply dogmatic rigid "nationally acceptable" standard treatments so that they will be judged by our QA people and on our lawyers to have met the "standard of care" but which may be devoid of many human aspects, and are certainly devoid of creativity and ingenuity.

What, specifically, can anaesthetists and departments of anaesthesia do about all this? First, we can speak out about efficacy and begin to perform multi-institutional trials of efficacy of various anaesthetic choices. For example, it is long overdue that we determine whether regional anaesthesia, for given procedures, is or is not safer or better than general anaesthesia. There are a number of creative ways in which this could be done, but all would require multi-institutional trials with hundreds of thousands of patients before we would likely come to reasonable answers. With 25 million anaesthetics performed annually in the United States, this is not as daunting a task as you might think. It must, however, involve the "private" anaesthesia sector or else it will not be valid. Will our "private practice" colleagues be willing to cross that daunting barrier into "research"? The same kinds of efficacy studies should be done for intraoperative invasive monitoring, comparisons of volatile anaesthetics between one another and vs intravenous anaesthetics, plus dozens of other valid clinical questions. If anaesthetists could take leadership roles in the above, it would raise the stature of our specialty and also help us provide better care for our patients.

Anaesthetists should also take leadership roles in their hospitals and should get behind these continuous quality improvement activities with real medical leadership. The operating room is often a contentious and difficult place from the standpoint of hospital administration. One can think of it as the "Straights of Hormuz" of the hospital, i.e., a narrow bottleneck. Anaesthetists getting behind total quality management methods that are helping to improve local practices will be seen as hospital leaders as well as medical community leaders.

Finally, will "quality" be forced on us from "outside"? One of the most disgusting banalities I hear from glib speakers these days about all sorts of problems is "if we don't do this it will be forced on us by ... ". I reject that banality because first, it is not true and, second, it is nearly always an invalid reason for doing something. Improvements in quality cannot really be forced upon us from the "outside" for the simple reason that the "outsiders" are nonphysicians. They can only place various forms of financial pressure on us. However, by far, the most important reason this banality disgusts me is that it is the wrong reason for doing anything. We must implement valid statistical quality measurement and understand the need to build quality into our processes all along the way. We clearly need to develop real measures of efficacy for the things we do and don't do in medicine. We must now work to understand the processes by which physicians are educated and build quality into that also all along the way. If we can do these things, we can begin to reverse the negative image that society is rapidly developing of our profession. If, instead, the activities of our national organizations (including our own in anaesthesia) continue along the lines of "preservation of income" then we are in for yet another decade of deterioration of our image and our feelings of self worth.

I received a phone call recently from a government official who asked me whether I thought it was appropriate to send a separate bill for the mediastinal tubes after a coronary bypass, i.e., billing for the mediastinal tubes under a separate CPT code! I have information that there are places where an anaesthesia record for labour epidural is started in routine fashion, but if that patient needs a Caesarean section, the anaesthesia record for the labour epidural is stopped and a new anaesthesia record is made out for a Caesarean section, and a bill is sent for the "second" epidural, separately. I am told 
there are many instances where anaesthetists are signing for "supervision" of nurse anaesthetics when in fact the anaesthetist was in another operating room doing an anaesthetic by himself/herself. I know of situations where a bill was sent for the placement of a Swan Ganz catheter under a CPT code reserved for "right heart catheterization," and other instances in which the bill for the Swan Ganz catheter included time units for the placement of the catheter despite the fact that the anaesthetist was charging separately for that time for anaesthesia care of the patient. There is an apparently widespread practice of allowing floor nurses to inject pain management epidurals with the anaesthetist, who was at home, nonetheless sending a bill (not to mention risking the patient?). Have we really let this much greed and avarice invade our profession or are these isolated incidents? These are aspects of "quality" that are also worthy of discussion and understanding, and then continuous improvement in our hospitals and clinics. I hope my dissertation has at least been somewhat thought-provoking. Thank you for reading this and listening to me.

\section{Acknowledgements}

I would like to acknowledge Dr. Niels Jensen's major contribution to this material by making him a co-author of this review course lecture.

\section{Suggested reading}

Berwick DM, Godfrey $A B$, Roessner J. Curing Healthcare:

New Strategies for Quality Improvement: A Report on the

National Demonstration Project on Quality Improvement in

Healthcare. San Francisco: Josie-Bass Publishers, 1990.

Bowen $O R$. Shattuck lecture - What is quality care? N Engl J Med 1987; 1578-80.

Couch $J B$, $(E d$.). Health Care Quality Management for the 21st Century. Tampa: American College of Physician Executives, 1991.

Donabedian $A$. The quality of care: how can it be assessed? JAMA 1988; 260: 1743-8.

Wennberg JE. The paradox of appropriate care. JAMA 1987; 258: 2568-9.

Vitez TS. A model for quality assurance in anesthesiology. J Clin Anesth 1990; 2: 280-7.

Buck N, Devlin HB, Lunn JN. The Report of the Confidential Enquiry Into Perioperative Deaths. London: Nuffield Provisional Hospitals Trust and the King's Fund for Hospitals, 1987. 


\title{
La gestion de la qualité totale: encore une autre marotte?
}

\author{
J.H. Tinker MD, N.F. Jensen MD
}

Aujourd'hui, en Amérique, la politique des soins de santé est propulsée par trois forces majeures: le contrôle des coûts, l'accessibilité aux soins et leur qualité. L'employeur tout comme le payeur exige un contrôle des coûts. Les politiciens continuent de débiter leurs torrents de platitudes sur l'accessibilité aux soins pour le non-assuré et le peu assuré. Trop souvent, l'activité de la médecine organisée se résume en trois ou quatre mots: on parle de " préservation du revenu " ou ce qui est pire de " préservation de son revenu ". Perdue dans tout ce charabia, la qualité demeure dans l'abandon.

A peu près toute lindustrie américaine veint de découvrir (et c'est surprenant!) qu'en affaires, il n'existe que trois moyens de compétition: le prix, l'accès et la qualité. La majorité des industriels américains comprennent maintenant ce que les Japonais ont compris il y a 40 ans. Grâce à W. Edwards Deming et de John Juran, ces derniers ont appris que la qualité annexée à un produit ou un service après sa conception originale, au cours de sa production et tout au long de sa vie utile, peut réduire les coûts, augmenter les profits, établir un climat de confiance auprès de client et devenir le point d'appui des progrès d'une compagnie ou d'une industrie (et même d'un pays).

Cette leçon a été douloureuse pour l'industrie. Quiconque a déjà possédé une Ford 1979 a connu le cauchemar de la qualité industrielle en Amérique. Pendant ces années horribles pour ses produits manufacturés, alors que la clientèle américaine se détournait vers les produits japonais et étrangers, un enquêteur après l'autre recherchait les motifs de cette décrépitude. On n'a pas cessé de leur répéter que c'était parce que les produits étrangers étaient supérieurs. Alors que le dernier des ignorants pouvait le constater, l'aveuglement des industriels était inexplicable. Pourquoi? La réponse est d'une importance capitale: jusque là, les industriels américans pensaient que la qualité était l'antithèse de la croissance et de la rentabilité. Ils croyaient comme à un dogme que la qualité coûtait plus cher.

Au début des années 50, deux individus parfaitement inconnus aux E.U.A., W. Edwards Deming de Boston et John Juran de New York, furent invités par des industriels japonais à se rendre dans leur pays pour fin de consultation. Ils vendirent rapidement lidée que la pro- duction éventuelle de marchandises de qualité nécessitait l'intégration du concept de qualité au tout début du mécanisme global de production, non a linspection finale comme la méthode traditionnelle américaine le voulait (méthode malheureusement toujours en vigueur dans certains domaines dont celui de la santé). Ils persuadèrent les Japonais qu'en introduisant la qualité à chaque étape de la production, ils diminueraient les pertes et les rejets et provoqueraient une baisse dramatique des coûts: cette baisse compenserait amplement pour le coût de la qualité. Les bénéfices accessoires pour les compagnies furent multiples, surtout sur le plan du moral. Alors qu'auparavant, on donnait un coup de bâton (financier ou véritable) sur la tête du travailleur sil produisait un objet défectueux, on lui donnait maintenant la responsabilité de réaliser un produit de qualité. L'amélioration du moral du travailleur japonais fut remarquable. Pendant ce temps, en Amérique, certains travailleurs sabotaient leurs produits (on a vu par exemple des cas où ils soudaient des petites boîtes en acier pleins d'écrous à l'intérieur des pare-chocs des automobiles pour provoquer un cliquetis irritant) et se permettaient toutes sortes de méfaits. Ce n'etaient que des symptômes de la maladie grave dont souffraient les secteurs manufacturiers et de services.

En Amérique, on finit par reconnaître Deming. Ses 14 articles font maintenant partie des connaissances essentielles de tout candidat au MBA. Agé de 91 ans, Deming est toujours très actif et continue de jouer un rôle important dans la poursuite de la revitalisation des secteurs de l'industrie et des services américains.

Pour comprendre le point essentiel de ce qui a été proposé par Deming, Juran et d'autres, on doit tenir compte de la différence philosophique fondamentale qui sépare ceux qui comprennent bien la nature humaine, et les industriels et gestionnaires américains qui ne la connaissaient pas. Deming croit que la grande majorité des travailleurs désirent confectionner des produits de qualité. La responsabilité de l'échec ne repose donc plus sur le travailleur mais plutôt sur le système et le procédé de fabrication. Il s'ensuit que les mêmes travailleurs doivent être capables d'assister la direction pour trouver le moyen d'améliorer le système. L'amélioration doit se continuer, d'où la terminologie "amélioration continue " ou "amélioration continue de la qualité ". En Amérique, 
le machiniste à qui il revient de produire une tige d'un pouce de diamètre recevra par exemple un devis qui mentionne par exemple, la dimension 1,000 pouce $\pm 0,002$. On présente au machiniste des quotas de production pour sa période de travail de huit heures. Au Japon, le même ouvrier reçoit un devis sur lequel on inscrit que la tige doit avoir la dimension la plus rapprochée possible d'un pouce et l'ordre d'en fabriquer dans sa journée et, s.v.p., le plus grand nombre et de la plus haute qualité qui soit. A chaque jour, l'administration vérifie et enregistre les résultats. $\mathrm{Si}$ on constate une erreur, on n'assume pas immédiatement que l'ouvrier flâne, s'amuse ou sabote mais que le matériel utilisé et la méthode de production sont peut-être défectueux. Cette attitude envers le travailleur a été le facteur déterminant de la révolution industrielle japonaise et d'ailleurs. Fait surprenant, les américains ont mis 40 ans pour l'adopter.

Ces concepts ne sont pas encore véritablement adaptés au domaine des soins de la santé. Aujourd'hui, la qualité des soins fait face à de nombreux problèmes. En réalité, on connaît mal les résultats des efforts fournis en soins sanitaires. On a l'impression que plusieurs des besoins sont mal couverts, alors que les dépenses accordées aux traitements inefficaces et inappropriés sont énormes. Plusieurs médecins abusent à outrance du système parce qu'ils s'imaginent qu'ils doivent pratiquer une médecine " défensive ". Nous pourrions citer des différences incroyable au regard des dépenses entre hôpitaux et régions. Nous assistons à une duplication massive des moyens disponibles, ex. l'installation généralisée de lithotripteurs, de tomodensitomètres, d'appareils d'imagerie magnétique, et maintenant de tomographes par positrons. Il ne fait plus aucun doute que les patients et leurs assureurs pensent quils payent trop cher, reçoivent trop peu de soins, que ces soins sont trop impersonnels; au regard de la qualité globale, de la disponibilité et du coût des soins, l'insatisfaction croît constamment. Le principal intérêt du bénéficiaire se porte maintenant sur la qualité de la médecine et non sur ses triomphes.

Les causes de ce mécontentement sont nombreuses. Par exemple, les dépenses attribuées aux soins de santé pour des populations comparables sont environ deux fois plus considérables à Boston qu’à New Haven. Des études montrent des différences de fréquences de deux à trois fois plus grandes pour les demandes d'épreuves de laboratoire, d'interventions et d'hospitalisations. Le docteur Jack Wennberg de Dartmouth est un observateur de ce phénomène en pleine croissance. Il a trouvé que dans un comté du Maine, $70 \%$ des femmes de 70 ans avaient été hystérectomisées alors que dans le comté voisin le pourcentage était de $20 \%$ seulement. Ceci est réellement inquiétant. Une autre étude considère que $65 \%$ des indications de l'endartérectomie carotidienne sont douteuses ainsi que $56 \%$ des implantations de pacemakers remboursées par le Medicare. Avant que ne commence le remboursement prospectif, les taux d'admission différaient de $22 \%$ entre les régions et de $45 \%$ entre les durées du séjour hospitalier.

Qu'est-ce qui se produit quand les médecins, les hôpitaux ou leurs associations professionnelles sont mis en face de ces données dignes de Ralph Nader? Souvent, le prestataire de soins trouve une façon compliquée et le baragouin approprié pour dire que ses patients sont plus malades que les autres. Déterminer la gravité d'une maladie est devenu maintenant une opération sophistiquée. Nous possédons maintenant de vastes bases de données. L'indexation de la gravité de la maladie produira dans le futur des résultats étonnants. Je doute que les centres médicaux universitaires aient nécessairement toujours à traiter les sujets les plus malades. Comme la plupart des hôpitaux, la majorité des médecins doit assurer le traitement d'une clientèle vraiment malade.

Présentement, nous dépensons pour la prestation des soins de santé $12 \%$ de notre produit national brut (PNB) c.-à-d. $12 \%$ de la valeur de tous les biens et services produits aux E.U.A. Plusieurs projections établissent que ce pourcentage grimpera à $15 \%$ en l'an 2000 . Aucune autre nation industrialisée ne dépense plus de $10 \%$ de son PNB pour la santé et la majorité dépense beaucoup moins. Si le système américain des soins de santé constituait une nation, cette nation aurait le sixième PNB de toutes les « vraies » nations de la planète.

Non seulement nous ne connaissons pas en quoi consiste la gestion de la qualité, c.-à-d. cette philosophie japonaise de l'amélioration continuelle de la qualité, mais nous n'en voulons pas. Sur plusieurs points, la médecine, incluant l'anesthésie, ressemble aux guildes du passé. Quand les petites "épiceries du coin " se sont vues menacées par les grandes chaînes commerciales, elles se sont groupées pour former des guildes; dans certains villes, on les a appelées IGA (Independent Grocers Association). Lidée principale était d'insérer sur le mot independant dans la raison sociale. Puis vinrent Kroger, Safeway, HyVee etc. et vous connaissez les résultats. La raison? Ma définition préféré du capitalisme est simple: le capitalisme se définit simplement comme l'investissement et l'utilisation du capital. L'Amérique corporative capitaliste s'attaque aux marchés reconnus en investissant et en utilisant le capital. Qu'on fait Safeway, Kroger, WinnDixie pour battre les " épiceries du coin "? Il ont compétionné avec les prix, la qualité et l'accessibilité. Ils ont construit de grandes surfaces, les ont gardée ouvertes plus longtemps, se sont efforcés de couper les prix et ont maintenu une qualité constante et souvent de niveau élevé.

La plupart des médecins sont béatement inconscients que l'investissement de capital, comme dans l'analogie uti- 
lisée auparavant, interviendra bientôt dans la prestation des soins de santé aux E.U.A. Pourquoi pas? Quand vous vous rendez chez Safeway, vous trouvez des produits de qualité, une grande sélection, des heures d'ouvertures excellentes, un vaste terrain de stationnement etc. Il est certain que vous n'aurez pas nécessairement accès à votre conseiller domestique et à votre boucher que vous appelez familièrement par leur nom et avec lesquels vous conversez amicalement régulièrement. Mais vous savez que la qualité des produits que vous achetez est soutenue par une grande organisation qui agit avec compétence et habileté. Des millions d'Américains ont recours à ce modèle de distribution alimentaire, pendant que les politiciens et les sondeurs continuent de regretter le bon vieux temps. Pourquoi ces consommateurs ne choisiraient-ils pas ce modèle corporatif pour la prestation des soins de santé? Selon toutes probabilités, les consommateurs prendront la direction du renouveau, si la prestation des soins profite d'un meilleur contrôle de la qualité et si cette qualité peut être continuellement perfectionnée. Le système sacré de la rémunération à l'acte n'a plus de sens. Nous soumettons un tarif, un troisième intervenant décide ce quil paiera, et, entre certaines limites, nous acceptons le paiement.

Comprenons-nous réellement que la pierre angulaire de tout ce processus se résume au mot qualité? Parmi les 6000 hôpitaux et plus des E.U.A., combien éprouvent des problèmes avec leur département d'anesthésie. De ces départements-problèmes, combien administrent des soins de qualité constamment améliorés? Bien sûr, chaque hôpital présente ses problèmes locaux et individuels; ils sont souvent caractérisés par des disputes entre individus et groupes qui s'écorchent mutuellement; ou encore par des professionnels qui essayent d'eliminer un concurrent, ex. anesthésiste vs infirmière-anesthésiste ou vice versa. Derrière tous ses écrans de fumée, la qualité disparaît. Savons-nous la définir? Le penseur avant-gardiste Donabedian a défini la qualité des soins médicaux comme " le type de soins susceptible de maximaliser un critère mesurable du bien-être du patient une fois qu'on a pesé les gains et pertes potentiels inhérents au processus global des soins ". C'est une façon académique et fort vague de dire que la qualité constitue quelque chose que la plupart d'entre nous croient connaître, mais, qu'en réalité chacun conçoit d'une façon différente. Nous ne savons vraiment pas comment la mesurer de façon objective et reproductible.

Entre les terms « qualité " et " efficacité " il existe une grande confusion. Une bonne façon de comprendre " qualité " est de répondre à la question suivante: estce que la bonne chose a été faite et a-t-elle été bien faite? Déterminer la qualité de cette façon exige une connaissance préalable de ce qui est efficace. Dans plu- sieurs domaines médicaux et spécialement en chirurgie, les fondations de l'efficacité sont pour le moins fragiles. Par exemple, avec les antibiotiques à notre disposition, devons-nous absolument continuer les appendicectomies? Toujours? Qu'en savons-nous? Nous savons que l'appendicite traitée chirurgicalement présente un taux relativement bas de mortalité et un faible risque anesthésique et chirurgical. Nous n'avons toutefois aucune idée s'il est maintenant devenu plus efficace d'utiliser l'antibiothérapie moderne.

En l'absence de base pour appuyer le concept d'efficacité, Wennberg raisonne qu'il faut contourner le problème. Si nous devons progresser et tenter d'établir des critères raisonnables de qualité, nous devons accepter un vaste assortiment d'indications thérapeutiques. Wennberg et plusieurs autres croient qu'il est très important d'évaluer les théories thérapeutiques rationnelles, mais non éprouvées, appliquées à des maladies courantes. Wennberg fait remarquer que dans les hôpitaux américains, $60 \%$ des admissions chirurgicales ne sont faites que pour 23 opérations différentes. Il rapporte aussi que $70 \%$ des admissions ne concernent que 40 maladies aiguë ou chroniques. C'est sur cette basse qu'il soutient que des études d'efficacité devraient être entreprises. D'autres, dont je suis, ne possèdent pas cet optimisme, car Wennberg semble ignorer, entre autres choses, la puissance économique que l'industrie exerce sur chaque thérapeutique médicale et chirurgicale.

Par exemple, la compagnie Sandoz peut commanditer un groupe de 100 spécialistes de la transplantation pour savoir si oui ou non les E.U.A. devraient émettre une loi portant une clause spécifique de refus de don d'organe, à défaut duquel les organes seront systématiquement prélevés après le décès ( $A M A$ News du 4 novembre 1991). Nous commençons tout juste à comprendre l'énorme influence de la finance sur certains traitements et son manque d'intérêt lorsqu'il s'agit d'en déterminer l'efficacité.

A part l'approche idéaliste "efficacité d'abord qualité ensuite " de Wennberg et ses collègues (qui vivent à Hanover, une petite ville de 6,000 habitants, du New Hampshire), que se passe-t-il dans le vaste monde? L'administration des soins de la santé (HCPA) coupe simplement le paiement des interventions qu'elle juge trop utilisées, peu efficaces ou les deux. Pour comprendre ce processus, on n'a qu'à regarder ce que l'HCPA a fait à l'angioplastie coronarienne ces dernières années. Bien que j'aie personnellement applaudi ces coupures pour cette manoeuvre très discutable, je connais l'arbitraire des décisions de l'HCPA. Dans plusieurs domaines, l'HCPA procède à des coupures d'honoraires arbitraires, souvent capricieuses, mais toujours commandées par des objectifs budgétaires et attend les réactions. Certains pensent que c'est la seule façon pratique de procéder. D'autres croient que toute 
nouvelle intervention ou tout nouveau traitement doit avoir fait la preuve de son efficacité avant d'obtenir un permis d'exploitation ou une rémunération. Accepteriezvous d'être dans le groupe de l'opération feinte dans une étude portant sur l'efficacité de l'appendicectomie? Si vous faisiez partie du groupe de l'opération feinte accepteriez. vous de subir une incision sans intervention et de recevoir des antibiotiques à hautes doses à la place. Il est probable que non. Je ne crois pas que les partisans des études de validation de l'efficacité puissent tenir le coup contre des interventions thérapeutiques financièrement bien ancrées. L'histoire nous montre surtout que nous les abandonnons pour des traitements plus sûrs ou mieux rémunérés plutôt que pour des questions d'efficacité.

Et l'assurance de qualité? Cette terminologie presque aberrante implique que nous avons déjà la qualité, que nous savons le mesurer avec confiance et que nous allons assurer sa pérennité. C'est absurde. Revenons aux méthodes japonaises de fabrication des tiges de 1,000 pouce de diamètre. Si les produits nécessitent la première qualité, le procédé ne sera pas nécessairement visé par des mesures immédiates décrétées par le responsable de l'amélioration continue de la qualité mais les administrateurs garderont l'oeil overt. Ils ne surveilleront pas le machiniste lui-même mais la qualité de son produit. $\mathrm{Si}$ avec le temps, celle-ci défaille, ils ne blâmeront pas systématiquement l'ouvrier. Ils continueront d'assumer que l'ouvrier fait son possible pour fabriquer en tout temps le meilleur produit possible avec le système à sa disposition. Je n'ai pas besoin de vous rappeler ce qu'un contremaître américain dirait et ferait. Le machiniste américain recevrait des quotas assortis d'une tolérance. Si ni l'un ni l'autre n'est rencontré, on blâmera l'ouvrier. Car en Amérique, c'est encore la mentalité du policeman qui règne.

Deming a dit que même si dans une compagnie chacun travaillait toujours au meilleur de sa capacité et avec les meilleures intentions, la compagnie ferait faillite si tous ces gens bien intentionnés, qui triment dur, ne travaillaient pas ensemble. Deming exige que la qualité soit introduite au tout début. Il croit qu'il faut s'organiser aux plus bas niveaux pour résoudre les problèmes. Tous les hôpitaux, et non seulement les hôpitaux d'enseignement accusent un retard sur la plupart des institutions modernes.

Partout en Amérique, particulièrement dans l'industrie et, de plus en plus dans les hôpitaux, on met en place des initiatives de gestion de la qualité totale. Quelques exemples peuvent illustrer ce point. La ponctualité de l'arrivée des patients en salle d'opération constitue souvent un problème. Un groupe de contrôle de la qualité peut être institué pour développer un organigramme dans le but de comprendre chacune des étapes associées au projet. L'idée même d'un tel processus, pour un projet si simple convaincra tout le monde de la complexité du problème. Le groupe de contrôle de la qualité est formé des individus qui font le travail, assistés d'une personne ressource en gestion de la qualité qui dirige les discussions. Lorsque tous comprennent la fonction de chacun avec ses problèmes, on constate non sans surprise le progrès réalisable. C'est l'essence même de la philosophie de l'amélioration continue de la qualité. C'est l'opposé du type d'assurance de la qualité qui est à la recherche perpétuelle d'un coupable (voir plus loin). La programmation des salles d'opération, le roulement, les inventaires exagérés d'instruments chirurgicaux, de microscopes, de lasers, de fibroscopes etc. sont tous des problèmes que peut solutionner une équipe de gestion de la qualité.

Deming conseille de développer une bonne relation à long terme avec les fournisseurs. Cette conduite rassure le fournisseur pour l'avenir et l'incite à améliorer ses produits. Que fait-on dans nos hôpitaux? Nous achetons des produits pharmaceutiques et de l'équipement sur la base hebdomadaire de la plus basse soumission. On prétend que, sur le point de partir pour son premier orbite, John Glenn aurait déclaré: " Me voici maintenant assis sur trois millions de pièces toutes achetées au plus bas prix ». Le concept de la plus basse soumission représente, la plupart du temps, l'antithèse même de la qualité.

Deming disait qu'il faut défoncer les clôtures. Que faiton dans nos départements d'anesthésie? Nous avons construit un monde pseudo-élitiste. Si je veux limiter la compétition, je n'ai qu'à former un comité et inventer une manière de certificat. Ceci est encore contraire à la qualité. Dans plusieurs des grand départements, nous avons des équipes de garde séparées pour la chirurgie cardiaque, la neurochirurgie, la pédiatrie, l'obstétrique, la gestion de la douleur etc. Il est absolument impensable, par exemple, que les anesthésistes du "bon vieux temps" puissent anesthésier le patient qui saigne après un pontage aortocoronarien. Deming disait qu'il fallait développer la fierté du métier. A mesure que nous érigeons des barrières élitistes, avec des journaux et des sociétés dédiés aux superspécialisés qui dédaignent les anesthésistes du " bon vieux temps ", comment ces derniers peuvent-ils être fiers de ce qu'ils font? Qu'arrive-t-il au superspécialisé quand vient subitement le temps de faire de la " bonne vieille anesthésie "?

Deming a dit qu'après l'inspection des produit qui sortent de l'usine, on reste avec trois piles: les pièces acceptables, celles qui iront à la ferraille (à grand prix) et celles qui sont rejetées mais qui devront être réusinées (à grand prix encore). On peut dire la même chose du débit de nos hôpitaux et de nos écoles de médecine. Selon Deming, il faut introduire la qualité sur toute la ligne; il ne faut pas la rechercher uniquement à la fin et s'attendre à ce qu'elle y soit. Que fait-on dans le domaine 
médical? Nous ne manifestons pratiquement aucun intérêt pour la qualité de nos programmes de formation pour étudiants en médecine et résidents. Il semble que nous soyons résignés à attendre que les examinateurs d'un organisme d'état ou l'Américan Board of Anesthesiology fasse passer des examens de compétence à la fin de la période de formation. Dans nos hôpitaux, essayons-nous d'intégrer sur toute la ligne la qualité à nos programmes de formation et de soins? Essayons-nous réellement de faire la même chose pour nos projets de recherche clinique et expérimentale? Nos méthodes de contrôle de la qualité sont improductives et incompatibles avec la qualité. Les méthodes de contrôle de la qualité actuellement gérées par les médecins nous obligent à rechercher un coupable si le résultat est mauvais. Dans chacun des états américain, des groupes de pression s'en chargent avec un esprit revanchard. La mentalité de la décapitation produit une attitude défensive et non une médecine de qualité. Est-ce utile? Vous connaissez la réponse comme Deming et Juran l'énoncaient il y a 40 ans. Je ne prétend pas qu'il faille absoudre les quelques vrais incompétents dont les procédés habituels sont la négligence, la médiocrité, le mensonge et la tricherie. Deming avait entièrement raison lorsqu'l énonçait que la grande majorité des travailleurs désiraient effectuer du bon travail et procurer des services de qualité. Nous devons écouter les travailleurs et adopter une philosophie de perfectionnement continu. Une utopie? Donnez-vous la peine d'examiner un appareil-photo ou une voiture japonaise.

Que penser de l'enseignement que nous avons reçu en médecine? Il est juste de dire qu'il a été long, rigide, quelquefois tyrannique et souvent dogmatique. Il fut loin de ce que Deming proposait pour l'épanouissement de l'individu, de son ingéniosité et de son potentiel. Avec un système aussi austère, est-il possible que les aspects humanitaires et généreux de la médecine qui nous ont d'abord attirés, se soient évanouis? Serions-nous rendus à regarder craintivement nos patients comme des adversaires éventuels devant les tribunaux au point de nous endurcir dans l'attitude antipathique et indifférente de gens dont le rôle ne consiste qu'à appliquer des standards de soins " acceptables "? Il reste à nos gestionnaires de la qualité des soins et à nos avocats de juger si nous avons bien rencontré les standards thérapeutiques mêmes si nos soins sont dénudés de tout humanisme, de toute créativité et de toute ingéniosité.

Comment les département d'anesthésie doivent-ils intervenir spécifiquement? D'abord, nous pouvons parler efficacité et réaliser des essais multicentriques sur l'efficacité du choix des anesthésiques. Par exemple, nous avons attendu trop longtemps pour déterminer si l'anesthésie régionale est, pour une intervention donnée, plus sûre ou meilleure que l'anesthésie générale. On peut faire cela de plusieurs façons imaginatives, mais toutes nécessitent des essais multicentriques portant sur des centaines de milliers de patients avant de pouvoir donner des réponses sensées. Avec les 25 millions d'anesthésie annuelles administrées aux E.U.A., la mission n'est pas si impossible que vous croyez. L'étude doit impliquer la pratique privée sinon elle ne serait pas valide. Nos collègues du secteur privé sont-il prêts à franchir la barrière intimidante de la recherche? Le même type d'étude d'efficacité devrait être entrepris sur le monitorage effractif, la comparaison entre eux des anesthésiques généraux, et sur plusieurs autres question d'intérêt clinique. Les anesthésistes devraient prendre linitiative de ces études, ce qui élèverait la stature de notre spécialité tout en nous permettant de procurer de meilleurs soins.

Les anesthésistes devraient aussi adopter des rôle des leaders dans leurs hôpitaux et ouvrir la voie aux activités dédiées à l'amélioration continue de la qualité. La salle d'opération est souvent considérée par l'administration comme un site de querelles et de problèmes. On peut imaginer la salle d'opération comme le "détroit d'Ormuz » de l'hôpital c.-à-d. comme un étroit goulot d'étranglement. Les anesthésistes qui appuyent les méthodes de gestion qualitative et qui participent à l'amélioration de la qualité seront perçus comme leaders hospitaliers autant que leaders de la communauté.

Finalement, serons-nous contraints par des force extérieures d'adopter la qualité? Une des banalités les plus dégoutantes que j'entend consiste à dire que si nous ne faisons pas une chose, on nous forcera à la faire. Je rejette cette affirmation d'abord parce qu'elle est fausse, et deuxièmement parce que c'est un agent de motivation non valide. Des améliorations à la qualité ne peuvent être imposées de l'extérieur, parce que les "étrangers " ne sont pas des médecins. Tout ce qu'ils peuvent faire, c'est d'exercer sur nous certaines formes de pression financière. $\mathrm{Ce}$ pendant, la raison de loin la plus importante pour laquelle cette platitude me déplait, c'est qu'elle constitue un bien mauvais motif d'action. Nous devons implanter des mesures statistiques de la qualité et comprendre la nécessité de lintégrer à tous les niveaux. Nous avons nettement besoin de développer en médecine de vrais critères d'efficacité pour les choses que nous faisons et celles nous omettons. Nous devons de plus nous efforcer de mieux connaitre dès maintenant le cheminement éducatif du médecin et $\mathrm{y}$ intégrer la qualité à tous ses niveaux. $\mathrm{Si}$ nous réussissons, nous renverserons limage de plus en plus négative que la société perçoit de notre profession. $\mathrm{Si}$, à la place, les activités de nos associations professionnelles nationales, incluant la nôtre, continuent dans la ligne de préservation de revenus, nous verrons pour une autre décennie notre image et notre fierté continuer de se détériorer. 
J'ai récemment reçu un appel téléphonique de la part d'un officiel du gouvernement qui me demandait s'il était approprié de remplir une requête séparée d'honoraires pour drainage médiastinal après un pontage aortocoronarien, c.-à-d. de facturer le drainage sous un code séparé du pontage. J'ai appris qu'il y a des endroits où le dossier d'anesthésie pour une épidurale pendant le travail est débuté comme d'habitude, mais si une césarienne devient nécessaire, on termine ce dossier; on en débute un nouveau pour la césarienne, et les deux actes sont facturés séparément. On m'a rapporté aussi que souvent, l'anesthésiste facturait pour la supervision d'une infirmière anesthésiste alors que lui-même, dans une autre salle d'opération, effectuait une anesthésie. Je connais des situations où des honoraires sont facturés pour la mise en place d'un cathéter de Swann-Ganz sous le code de cathétérisme du coeur droit, et qu'en même temps l'anesthésiste facture pour l'anesthésie. Il existe apparemment une pratique courante qui laisse aux infirmières le soin d'administrer des analgésiques épiduraux alors que l'anesthésiste reste chez lui mais facture l'acte séparément (et le risque quil fait subir au patient?). Avons-nous laissé l'avarice et la cupidité envahir notre profession ou sontce là des incidents isolés? Ces aspects de la qualité méritent d'être discutés et compris d'abord; par la suite nous pourrons parler d'amélioration continue de la qualité dans nos hôpitaux et nos cliniques. J'espère que cette dissertation aura eu au moins l'effet de provoquer. Merci de votre attention.

Je tiens à souligner l'importante contribution du Dr. Niels Jensen co-auteur de cette conférence d'actualisation.

\section{Références}

(Voir page R35). 